\title{
Effect of Substituting Alfalfa by Wheat Straw Powder on Rumen Digestion, Metabolism and Production Performance in Lactating Dairy Cows
}

\author{
Xueyan Lin*, Zhiyong Hu*, Na Li*, Qiuling Hou, Yun Wang, Jun Peng, Yue Jiang, Zhonghua Wang\# \\ College of Animal Science, Shandong Agricultural University, Taian, Shandong Province, China \\ Email: "zhwang@sdau.edu.cn
}

How to cite this paper: Lin, X.Y., Hu, Z.Y., Hou, Q.L., Wang, Y., Peng, J., Jiang, Y. and Wang, Z.H. (2019) Effect of Substituting Alfalfa by Wheat Straw Powder on Rumen Digestion, Metabolism and Production Performance in Lactating Dairy Cows. Advances in Bioscience and Biotechnology, 10, 197-217.

https://doi.org/10.4236/abb.2019.108015

Received: June 17, 2019

Accepted: August 13, 2019

Published: August 16, 2019

Copyright $\odot 2019$ by author(s) and Scientific Research Publishing Inc. This work is licensed under the Creative Commons Attribution International License (CC BY 4.0).

http://creativecommons.org/licenses/by/4.0/

\section{(c) (i) Open Access}

\begin{abstract}
China has abundant straw resources. However, the straw has high levels of crude fiber, low levels of crude protein and fat, poor palatability and low digestibility and a large volume. This study explored the feasibility of using wheat straw powder to replace some of alfalfa and the suitable replacement ratio for lactating dairy cows. In this trial, cows in the mid-lactation stage were fed with rations in which alfalfa hay was replaced isocalorically and isonitrogenously at $0 \%, 20 \%, 40 \%$ and $60 \%$ by wheat straw powder to explore the rumen metabolism and production performance of lactating dairy cows. Using a large randomized block design, 60 cows were selected and divided into 4 groups: the positive control group CG ( $0 \%$ replacement), and groups AL (20\% replacement), AM (40\% replacement), and $\mathrm{AH}$ (60\% replacement). The pre-feeding period was 2 weeks and the trial period was 8 weeks. Milk yield, milk protein yield, milk protein percentage, lactose yield, lactose percentage, milk fat yield, and milk fat percentage were not affected by the diets, and the differences among the groups were not significant $(P>0.05)$. The results show that replacing $20 \%$ alfalfa with wheat straw powder is most beneficial to production. When only the feed costs were considered, without considering other costs (such as labor, machinery, etc.) in the economic benefit calculation process, and assume that other costs are the same among the groups, and the economic benefits obtained by the AL group were the largest. The experimental results provide a basis for the further development of straw feed.
\end{abstract}

\footnotetext{
${ }^{\star}$ Have equal contribution to this article.

\#Correspondent author.
} 


\section{Keywords}

Wheat Straw Powder, Alfalfa, Production Performance, Digestion Metabolism, Cow

\section{Introduction}

China has abundant straw resources. However, the straw has high levels of crude fiber, low levels of crude protein and fat, poor palatability and low digestibility and a large volume [1]. The quality of forages and concentrates has a great impact on the performance of the cow. Alfalfa hay is considered to be a high-quality pasture, has a lower fiber content and a higher protein content. Compared to alfalfa, wheat straw as a forage results in lower dry matter intake (DMI) due to higher acid detergent fibers (NDF) (Shaver et al. 1988) [1]. Waldo and Jorgensen (1981) also reported that the intake of beans was $28 \%$ higher than that of hay with equivalent digestibility [2]. The fiber type of ruminant diets plays an important role in maintaining an optimal VFA level, which can affect rumen fermentation and animal behavior (Murphy et al. 2000; Robinson 1997; Sudweeks 1997) [3] [4] [5]. It has been reported that the use of comminuted wheat straw to replace half of alfalfa of the low fiber and high rumen degradable starch increases feed intake and standard milk production (Kalscheur et al. 2006) [6]. In general, we believe that when a diet contains higher levels of wheat straw, the feed intake of the cows will be reduced, which will not meet the nutritional needs, resulting in decreased milk production [7] [8]. If the straw is properly processed and modified to improve straw utilization, some high-quality forages such as alfalfa in the total mixed ration (TMR) may be replaced, without affecting the milk yield and reducing the cost of feed. This study explored the feasibility of using wheat straw powder to replace some of alfalfa and the suitable replacement ratio for lactating dairy cows. On one hand, this research can make full use of the existing straw feed resources in China. On the other hand, it is expected to reduce the cost of feeding.

\section{Materials and Methods}

\subsection{Animals}

Sixty Chinese Holstein healthy cows at mid-lactation (121 \pm 36 lactating days) were allocated to 4 groups according to the weight $(631 \pm 51 \mathrm{~kg})$ and similar parity. Cows were fed at 8:30, 17:30, 01:00 every day, the feed residue is controlled within $10 \%$. The leftover material is cleaned and weighed before feeding, and fed after milking. Free drinking water was provided throughout the day.

\subsection{Trial Design}

The trial employed a randomized block design. Sixty lactating cows were divided into four groups, respectively receiving a ration of different wheat straw gradient 
$(0 \%, 20 \%, 40 \%$, and $60 \%)$. The crude protein (CP) and energy levels of the four groups of diets were the same. The pre-feeding period was 2 weeks, and the trial period was 8 weeks.

\subsection{Rations}

Four rations were designed, where alfalfa was replaced by wheat straw, respectively at $0 \%, 20 \%, 40 \%$, and $60 \%(\mathrm{DM})$. The rations were formulated according to the NRC standard (USA 2001). The ingredient of the diet and nutrient compositions are shown in Table 1 . The concentrate to roughage ratio of the diets was 48:52 (DM basis). The composition of the concentrates of each ration was similar.

Table 1. Ingredients and chemical composition of the experimental diets.

\begin{tabular}{|c|c|c|c|c|}
\hline \multicolumn{5}{|c|}{ Diet ingredients (\% of DM) } \\
\hline Item & CG & $\mathrm{AL}$ & $\mathrm{AM}$ & $\mathrm{AH}$ \\
\hline Alfalfa hay & 18.36 & 14.63 & 11.01 & 7.38 \\
\hline Wheat straw powder & 0.00 & 3.66 & 7.34 & 11.06 \\
\hline Distillers grains & 3.55 & 3.53 & 3.54 & 3.56 \\
\hline Corn silage & 25.33 & 25.22 & 25.31 & 25.46 \\
\hline Beetroot & 4.31 & 4.29 & 4.66 & 4.69 \\
\hline Flaked corn & 20.81 & 19.62 & 17.72 & 15.85 \\
\hline Wheat bran & 4.30 & 4.29 & 4.30 & 4.37 \\
\hline Soybean meal & 12.44 & 13.89 & 15.31 & 16.75 \\
\hline Cottonseed & 3.39 & 3.37 & 3.29 & 3.31 \\
\hline${ }^{1}$ Premix & 2.15 & 2.14 & 2.14 & 2.16 \\
\hline Calcium hydrogen phosphate & 1.88 & 1.87 & 1.88 & 1.89 \\
\hline salt & 0.54 & 0.53 & 0.54 & 0.54 \\
\hline Baking soda & 1.07 & 1.07 & 1.07 & 1.08 \\
\hline magnesium oxide & 0.43 & 0.43 & 0.43 & 0.43 \\
\hline potassium chloride & 0.27 & 0.27 & 0.27 & 0.27 \\
\hline Fat & 0.81 & 0.80 & 0.80 & 0.81 \\
\hline Yeast culture & 0.39 & 0.38 & 0.39 & 0.39 \\
\hline \multicolumn{5}{|c|}{ Chemical composition (\% DM) } \\
\hline $\mathrm{CP}$ & 16.68 & 16.68 & 16.67 & 16.68 \\
\hline NDF & 31.50 & 32.64 & 34.03 & 35.42 \\
\hline $\mathrm{ADF}$ & 19.85 & 20.49 & 21.29 & 22.11 \\
\hline $\mathrm{NDF}$ & 24.13 & 25.18 & 26.58 & 27.89 \\
\hline${ }^{2} \mathrm{NFC}$ & 36.04 & 35.06 & 33.78 & 32.45 \\
\hline Fat & 3.24 & 3.17 & 3.07 & 2.30 \\
\hline $\mathrm{Ca}$ & 1.35 & 1.35 & 1.35 & 1.35 \\
\hline $\mathrm{P}$ & 0.53 & 0.53 & 0.53 & 0.53 \\
\hline NEL (Mcal/kg) & 1.59 & 1.59 & 1.57 & 1.56 \\
\hline
\end{tabular}

Note: ${ }^{~}$ Pre-mix contained VA, 260 KIU/kg; VD3, 50 KIU/kg; VE, 300 mg/kg; P, 84 mg/kg; Mn, 276 mg/kg; Zn, $1032 \mathrm{mg} / \mathrm{kg}$; Salt, $80 \mathrm{mg} / \mathrm{kg}$; Ca, $200 \mathrm{mg} / \mathrm{kg}$; Cu, $380 \mathrm{mg} / \mathrm{kg} ; \mathrm{Fe}, 180 \mathrm{mg} / \mathrm{kg} .{ }^{2} \mathrm{NFC}=100-(\% \mathrm{NDF}+\% \mathrm{CP}$ $+\% \mathrm{EE}+\%$ Ash). 
Each group of cows was randomly assigned to one of the 4 rations respectively:

1) Control group (CG, replaced 0\%)

2) AL group (replaced 20\%)

3) AM group (replaced 40\%)

4) AH group (replaced 60\%)

The ration for each group contained the same levels of energy and nitrogen. The crude protein content was $16.7 \%$, and the net energy NEL of the diet was 1.6 $\mathrm{Mcal} / \mathrm{kg}$. Cows were fed regularly with some salt to meet the demand for minerals.

\subsection{Sample Collection and Analysis}

\subsubsection{Ration Sample Preparation and Analysis}

Starting from the beginning of the trial period, the amounts of supplied and remaining feed of each cow were continuously measured and recorded for the first three days of each week. Feed and residual samples were collected weekly. All samples were dried at $65^{\circ} \mathrm{C}$ to determine the initial moisture, and crush to $1 \mathrm{~mm}$ using a shredder. Feed and residual samples were mainly used for the determination of dry matter (DM), CP, neutral detergent fiber (NDF), acidic detergent fiber (ADF), total energy (GE), ash (Ash), acid insoluble ash (AIA), calcium (Ca), and phosphorus (P).

\subsubsection{Milk Sample Collection}

An automatic milk production recording system was used to record the daily milk production. Milk samples were collected in the last three days of the 5th and 7th week of the trial period. The collected milk samples were mixed at a ratio of 4:3:3 with respect to samples from the morning, noon and evening. The milk samples were mixed with potassium dichromate as a preservative, then placed at $-4^{\circ} \mathrm{C}$ and immediately sent to the Jinan Dairy DHI Measurement Center for determination of milk fat, milk protein, lactose, total solids (TS) and milk urea nitrogen (MUN).

\subsubsection{Urine and Feces Sample Collection}

At the 5th and 7th week of the trial period, the excrements were collected by point sampling (Leonardi, 2003) [9] (first day: 6:00, 12:00, 18:00; second day: 1:00, 7: 00, 14:00; third day: 10:00, 21:00). Urine samples were collected by the genital massage stimulation method, and a sample of $20 \mathrm{ml}$ of urine was collected at the middle of urination. The urine samples were quickly mixed with $0.072 \mathrm{~N} \mathrm{H}_{2} \mathrm{SO}_{4}$ at a ratio of 1:4 for nitrogen fixation. Eight initial samples were mixed to make one testing sample, which was stored at $-20^{\circ} \mathrm{C}$ for determination of urinary nitrogen and creatinine. The fecal sample was taken directly from rectal feces. Eight initial fecal samples were mixed in proportion, dried at $65^{\circ} \mathrm{C}$ and pulverized to $1 \mathrm{~mm}$, and then measured for DM, CP, NDF, ADF, Ashand AIA. 


\subsubsection{Ruminal Fluid Collection}

On the last day of the 8th week of the trial period, before feeding in the morning, 5 cows were randomly selected from each group to collect rumen fluid. A gastric tube rumen fluid sampler was used to collect rumen fluid from multiple sites in the rumen (dorsal anterior, dorsal posterior, ventral anterior, ventral posterior, and centric). The samples were filtered through 4 layers of gauze. The rumen $\mathrm{pH}$ was measured. An aliquot of $5 \mathrm{ml}$ rumen fluid sample was mixed with $1 \mathrm{ml}$ of $25 \%(\mathrm{wt} / \mathrm{vol}) \mathrm{HPO}_{3}$ and stored at $-20^{\circ} \mathrm{C}$ for determination of VFA.

\subsubsection{Blood Collection}

At the 5th and 7th week of the trial period, after the milking in the morning and afternoon, blood samples were collected from the tail vein, incubated at $37^{\circ} \mathrm{C}$ in a water bath for $1 \mathrm{~h}$. The samples were centrifuged at $3500 \mathrm{rpm}$ for $15 \mathrm{~min}$ to separate the serum. The following hormones were measured: insulin (INS), glucagon (GLN), following routine blood indicators were measured: free fatty acids (FFA), urea nitrogen (BUN), blood glucose (GLU), beta-hydroxybutyrate (BHBA), and triglycerides (TG).

\subsection{Determination Methods}

\subsubsection{Method for Determining Routine Dietary Indices}

$\mathrm{DM}$ in the diet, residue and fecal samples were determined according to the method of GB 6435-86.

The OM content in the test diet, residue and fecal samples was calculated by the Ash content from the DM content.

The method of GB/T 6432-94 was used to determine CP in the test diet, residue and fecal samples.

The method of GB/T 20806-2006 was used to determine NDF in the test diet, residue and fecal samples.

The method of NY/T 1459-2007 was used to determine ADF in the test diet, residue and fecal samples.

The method of GB/T 6438-86 was used to determine crude ash in the diet, residue and fecal samples.

Total energy of feed ingredients was determined using a PAR 6200 oxygen bomb calorimeter.

Feed raw material calcium was determined using the method of GB/T 6436-2002.

Feed raw material phosphorus were determined using the method of GB/T 6437-2002. Determination of Milk Composition.

The milk component was measured using a near-infrared milk component analyzer (Foss-4000; Foss Electric; Hillerød; Denmark).

\subsubsection{Determination of Serum Biochemical Indices}

Serum biochemical indices were determined using a fully automated biochemical analyzer (Hitachi, type 7020). The pure urea nitrogen (PUN) kit was produced by Nanjing Jiancheng Biotechnology Co., Ltd. (Nitrate Reductase Method, 
Cat. No. A012).

The glucose (GLU) kit was produced by Sichuan Mike Biotechnology Co., Ltd.

The cortisol test kit was a product of Nanjing Jiancheng Biotechnology Co., Ltd.

The triglyceride (TG) kit was a product of Nanjing Jiancheng Biotechnology Co., Ltd. (GPO-PAP Enzyme Method, Cat. No. A110-2).

The $\beta$-hydroxybutyric acid (BHBA) kit was a product of Nanjing Jiancheng Biotechnology Co., Ltd.

\subsubsection{Serum Hormone Detection}

The levels of INS, GLN, IGF-1, GH, PRL and cortisol were measured by Nanjing Aoqing Company Immunoassay. The kit was purchased from Tianjin Jiuding and Tianjin Xiehe Pharmaceutical Technology Co., Ltd.

\subsubsection{Detection of Rumen VFA}

Rumen $\mathrm{pH}$ was measured using a JENCO 6178 benchtop pH/electrochemical meter (USA). The measurement of VFA was carried out with the method described by Yang and Varga (1989).

\subsubsection{Detection of Creatinine and Urea in Urine Samples}

Creatinine was measured using the protein-depleted picric acid colorimetric kit (Nanjing Jiancheng Biotechnology Co., Ltd.). Urea nitrogen was determined using a diacetyl hydrazine kit (Nanjing Jiancheng Biotechnology Co., Ltd.).

\subsection{Data Analysis}

Covariance analysis was employed for repeated data. The test data on the first day of the trial period was used as a covariate. The data was first processed using Excel, then further analyzed with the GLM process of SAS 8.2 software. Duncan's multiple comparisons were used to test the significance of the differences between the means of each group. $\mathrm{P}<0.05$ was considered significant. $0.05<\mathrm{P}<$ 0.1 was considered a trend of statistically significant. $\mathrm{P}>0.1$ was considered not significant.

\section{Results}

\subsection{Effects of Alfalfa Substitution by Wheat Straw on Nutrient Intake and Apparent Digestibility}

As shown in Table 2, the intakes of DM, CP NDF and OM were significantly affected by the diet $(\mathrm{P}<0.05)$. The $\mathrm{CP}$ intake was the highest in the AH group. The increased proportion of wheat straw substitution resulted in a significantly increased intake of NDF in the $\mathrm{AL}$ and $\mathrm{AH}$ groups compared with in the control group except for the AM group. The AH group had the largest value of NDF intake. The intakes of ADF by the test groups were significantly higher than that by the control group.

In this experiment, alfalfa hay was replaced by wheat straw powder from $0 \%$ 
Table 2. Effect of wheat straw on nutrient intake and apparent digestibility in dairy cows.

\begin{tabular}{ccccccc}
\hline Item & CG & AL & AM & AH & SEM & P-value \\
\hline DM & $20.84^{\mathrm{b}}$ & $21.57^{\mathrm{a}}$ & $20.81^{\mathrm{b}}$ & $21.76^{\mathrm{a}}$ & 0.14 & 0.02 \\
$\mathrm{OM}$ & $20.05^{\mathrm{ab}}$ & $20.88^{\mathrm{a}}$ & $19.76^{\mathrm{c}}$ & $20.04^{\mathrm{bc}}$ & 0.14 & 0.01 \\
$\mathrm{CP}$ & $3.33^{\mathrm{b}}$ & $3.60^{\mathrm{a}}$ & $3.37^{\mathrm{b}}$ & $3.63^{\mathrm{a}}$ & 0.03 & $<0.01$ \\
$\mathrm{NDF}$ & $7.62^{\mathrm{b}}$ & $8.27^{\mathrm{a}}$ & $7.86^{\mathrm{b}}$ & $8.40^{\mathrm{a}}$ & 0.08 & $<0.01$ \\
$\mathrm{ADF}$ & $3.36^{\mathrm{c}}$ & $3.71^{\mathrm{b}}$ & $3.77^{\mathrm{b}}$ & $4.04^{\mathrm{a}}$ & 0.04 & $<0.01$ \\
\hline & & Apparent digestibility $(\%)$ & & 0.19 \\
\hline $\mathrm{DM}$ & $59.49^{\mathrm{ab}}$ & $63.15^{\mathrm{a}}$ & $59.45^{\mathrm{a}}$ & $55.04^{\mathrm{b}}$ & 1.27 & 0.01 \\
$\mathrm{OM}$ & $61.35^{\mathrm{ab}}$ & $64.95^{\mathrm{a}}$ & $62.18^{\mathrm{a}}$ & $57.83^{\mathrm{b}}$ & 0.76 & $<0.01$ \\
$\mathrm{CP}$ & $67.12^{\mathrm{a}}$ & $66.31^{\mathrm{a}}$ & $63.22^{\mathrm{a}}$ & $58.85^{\mathrm{b}}$ & 0.83 & 0.13 \\
$\mathrm{NDF}$ & 49.76 & 50.67 & 48.03 & 45.49 & 0.83 & 0.90 \\
\hline ADF & 38.72 & 39.64 & 40.02 & 37.10 & 1.17 & \\
\hline
\end{tabular}

Note: Values within the same row without a shoulder note or noted with common letters were not significant $(P>0.05)$, those without a shared letter are significantly different $(P<0.05)$. CG, AL, AM, AH are the groups where wheat straw replaced alfalfa, respectively, $0 \%, 20 \%, 40 \%, 60 \%$.

to $60 \%$. There were significant differences in the apparent digestibility of organic matter and crude protein $(\mathrm{P}<0.05)$ among the rations. The AL group showed the highest DM digestibility. The apparent digestibility of $\mathrm{CP}$ in the largest replacement group $(\mathrm{AH})$ was significantly lower $(\mathrm{P}<0.05)$. The apparent digestibility of DM, NDF and ADF was not significantly different among groups ( $\mathrm{P}>$ $0.05)$.

\subsection{Effects of Wheat Straw Replacing Alfalfa on Nitrogen Metabolism}

As shown in Table 3, the nitrogen intake was extremely significantly affected by the diet treatment $(\mathrm{P}<0.05)$. Nitrogen intakes in the $\mathrm{CG}$ and $\mathrm{AL}$ groups were significantly higher than those in the AM and AH groups $(\mathrm{P}<0.05)$. The milk nitrogen, fecal nitrogen, urine nitrogen, and their ratios to nitrogen intake were not significantly different among the groups $(\mathrm{P}>0.05)$. Although the difference in nitrogen balance among groups was not significant $(\mathrm{P}>0.05)$, the nitrogen balance in the $\mathrm{AL}$ group was the highest in value.

\subsection{Effect of Wheat Straw Substituting Alfalfa on Rumen Fermentation Indexes}

As shown in Table 4, there were no significant differences among groups in acetic acid, propionic acid, butyric acid, isobutyric acid, valeric acid, isovaleric acid and rumen $\mathrm{pH}$ values $(\mathrm{P}>0.05)$. The total VFA content of the AL group was the highest in value. A greater substitution proportion was accompanied by the gradual increase in the ratio of ethylene-propylene, although the difference 
Table 3. Effect of wheat straw on nitrogen metabolism in dairy cows.

\begin{tabular}{ccccccc}
\hline Item & CG & AL & AM & AH & SEM & P-value \\
\hline Intake-N (kg/d) & $0.58^{\mathrm{b}}$ & $0.58^{\mathrm{b}}$ & $0.53^{\mathrm{a}}$ & $0.53^{\mathrm{a}}$ & 0.01 & $<0.01$ \\
Milk-N (kg/d) & $0.17^{\mathrm{ab}}$ & $0.17^{\mathrm{a}}$ & $0.17^{\mathrm{a}}$ & $0.15^{\mathrm{b}}$ & 0.01 & 0.12 \\
Fecal N (kg/d) & 0.22 & 0.20 & 0.21 & 0.21 & 0.01 & 0.80 \\
Urine N (kg/d) & 0.18 & 0.19 & 0.17 & 0.16 & $<0.01$ & 0.17 \\
$\begin{array}{c}\text { Urine N + Fecal N } \\
\text { (kg/d) }\end{array}$ & 0.39 & 0.39 & 0.39 & 0.38 & 0.01 & 0.85 \\
$\quad$ & & & & & & \\
N balance & 0.60 & 0.65 & 0.60 & 0.60 & 0.01 & 0.23 \\
Ratio to intake N & & & & & & \\
Milk-N & 0.29 & 0.30 & 0.32 & 0.29 & 0.01 & 0.12 \\
Urine N & 0.31 & 0.34 & 0.32 & 0.31 & 0.02 & 0.59 \\
Fecal N & 0.37 & 0.35 & 0.39 & 0.40 & 0.02 & 0.27 \\
Urine N + Fecal N & 0.68 & 0.68 & 0.72 & 0.71 & 0.01 & 0.64 \\
\hline
\end{tabular}

Note: Values in the same row without a shoulder note or noted with common letters were not significant $(\mathrm{P}>0.05)$, and those without a shared letter are significantly different $(\mathrm{P}<0.05) . \mathrm{CG}, \mathrm{AL}, \mathrm{AM}$, $\mathrm{AH}$ are the groups where wheat straw replaced alfalfa, respectively, $0 \%, 20 \%, 40 \%, 60 \%$.

Table 4. Effect of wheat straw on rumen fermentation indexes.

\begin{tabular}{ccccccc}
\hline & CG & AL & AM & AH & SEM & P-value \\
\hline Rumen pH & 6.78 & 6.94 & 6.74 & 6.82 & 0.07 & 0.79 \\
\hline Total VFA & 85.14 & 87.59 & 86.34 & 85.46 & 4.34 & 1.00 \\
Acetic & 49.81 & 49.82 & 51.12 & 51.28 & 3.35 & 0.10 \\
Propionic & 19.61 & 18.90 & 18.41 & 18.38 & 0.60 & 0.92 \\
Propionic & 2.99 & 3.15 & 3.27 & 3.27 & 0.06 & 0.22 \\
acid ratio & & & & & & \\
Butyrate & 8.23 & 8.17 & 8.17 & 8.25 & 0.28 & 1.00 \\
Isobutyric & 0.55 & 0.59 & 0.56 & 0.58 & 0.03 & 0.96 \\
Valerate & 0.92 & 1.05 & 1.09 & 1.07 & 0.07 & 0.88 \\
Isovaleric & 1.17 & 1.35 & 1.33 & 1.31 & 0.08 & 0.90 \\
\hline
\end{tabular}

Note: Values in the same row without a shoulder note or noted with common letters were not significant $(P>0.05)$, and those without a shared letter are significantly different $(P<0.05) . C G, A L, A M$, $\mathrm{AH}$ are the groups where wheat straw replaced alfalfa, respectively, $0 \%, 20 \%, 40 \%, 60 \%$.

among groups was not entremely significant $(\mathrm{P}>0.05)$.

\subsection{Effect of Wheat Straw Replacing Alfalfa on Lactation Performance}

As shown in Table 5, the diets did not affect the milk yield, milk protein yield, milk protein percentage, lactose yield, lactose percentage, milk fat yield, and milk fat percentage, and the differences among the groups were not significant 
Table 5. Effect of wheat straw replacing alfalfa on the performance of dairy cows.

\begin{tabular}{ccccccc}
\hline Item & CG & AL & AM & AH & SEM & P-value \\
\hline Milk yield (kg/d) & 28.13 & 29.33 & 27.56 & 26.07 & 0.56 & 0.28 \\
Protein yield (kg/d) & 1.07 & 1.11 & 1.10 & 0.97 & 0.02 & 0.12 \\
Milk protein (\%) & 3.80 & 3.86 & 3.99 & 3.86 & 0.05 & 0.49 \\
Lactose yield (kg/d) & 1.45 & 1.52 & 1.42 & 1.32 & 0.03 & 0.21 \\
Lactose (\%) & 5.15 & 5.05 & 5.17 & 4.99 & 0.05 & 0.56 \\
Fat yield (kg/d) & 0.85 & 0.84 & 0.88 & 0.74 & 0.03 & 0.33 \\
Fat (\%) & 3.09 & 3.13 & 3.23 & 3.09 & 0.12 & 0.98 \\
MUN (mg/dL) & $24.45^{\mathrm{a}}$ & $23.26^{\mathrm{ab}}$ & $23.40^{\mathrm{ab}}$ & $20.93^{\mathrm{b}}$ & 0.46 & 0.04 \\
4\% FCM (kg/d) & 24.04 & 24.32 & 24.21 & 21.49 & 0.49 & 0.16 \\
TS (\%) & 12.74 & 12.76 & 13.06 & 12.81 & 0.15 & 0.75 \\
ECM (kg/d) & 26.46 & 26.97 & 26.87 & 23.62 & 0.51 & 0.08 \\
Milk NE $(\mathrm{kg} / \mathrm{d})$ & 19.66 & 20.04 & 19.98 & $17 . .55$ & 0.38 & 0.97 \\
Feed efficiency & 1.29 & 1.41 & 1.28 & 1.25 & 0.03 & 0.16 \\
\hline
\end{tabular}

Note: Values in the same row without a shoulder note or noted with common letters were not significant $(\mathrm{P}>0.05)$, and those without a shared letter are significantly different $(\mathrm{P}<0.05)$. CG, AL, AM, AH are the groups where wheat straw replaced alfalfa, respectively, $0 \%, 20 \%, 40 \%, 60 \%$. 4\% FCM $=[15 \times$ Fat $(\%)+0.4] \times$ mild yield $(\mathrm{kg} / \mathrm{d})$; Feed efficiency $=$ Milk yield/DMI; NEL $(\mathrm{Mcal} / \mathrm{d})=$ milk yield $\times(0.0929 \times$ milk fat $(\%)+$ $0.0563 \times$ milk protein $(\%)+0.0395 \times$ milk lactose $(\%)(\mathrm{NRC}, 2001) ; \mathrm{ECM}(\mathrm{kg} / \mathrm{d})=$ milk yield $\times[(38.3 \times$ milk fat $(\%) \times 10+24.2 \times$ milk protein $(\%) \times 10+16.54 \times$ milk lactose $(\%) \times 10+20.7) \div 3140]$.

$(\mathrm{P}>0.05)$. The AL group showed the highest values of milk protein yield and lactose yield, but the AM group showed the highest values of milk protein percentage and the lactose percentage. The AM group had the highest values of milk yield and milk fat percentage.

The MUN content in the MH group was significantly lower than those in the other three groups $(\mathrm{P}<0.05)$. The diets did not significantly affect whole solids, $4 \%$ fat corrected milk, energy-corrected milk, net energy of lactation, and feed efficiency $(P>0.05)$. The energy corrected milk in the AM group was the highest numerically. In terms of feeding efficiency, although there was no significant difference among the groups, the $\mathrm{AL}$ group was the highest in value and the $\mathrm{AH}$ group was the smallest numerically.

\subsection{Effect of Wheat Straw Replacing Alfalfa on Serum Hormone}

As shown in Table 6, the differences among groups in the levels of serum insulin, glucagon, growth hormone and cortisol were not significant $(P>0.05)$. The differences among groups in serum insulin-like growth factor and prolactin levels were extremely significant $(\mathrm{P}<0.01)$. The concentrations of insulin-like growth factor and prolactin were numerically the largest in the CG group, and those in the AH group were the smallest in value. 
Table 6. Effect of wheat straw replacing alfalfa on blood hormones in dairy cows.

\begin{tabular}{ccccccc}
\hline Item & CG & AL & AM & AH & SEM & P-value \\
\hline Insulin (uIU/ml) & 11.56 & 10.75 & 10.00 & 11.53 & 0.24 & 0.06 \\
Glucagon (pg/ml) & 82.79 & 83.35 & 85.10 & 82.86 & 1.08 & 0.87 \\
IGF-I (ng/ml) & $122.25^{\mathrm{a}}$ & $113.91^{\mathrm{b}}$ & $101.25^{\mathrm{c}}$ & $112.83^{\mathrm{b}}$ & 1.59 & $<0.01$ \\
PRL (ng/ml) & $763.61^{\mathrm{a}}$ & $740.34^{\mathrm{ab}}$ & $715.28^{\mathrm{bc}}$ & $692.06^{\mathrm{c}}$ & 6.48 & $<0.01$ \\
GH (ng/ml) & 18.49 & 16.39 & 15.78 & 15.82 & 0.31 & 0.06 \\
Cortisol (ug/L) & 85.61 & 83.23 & 81.85 & 82.04 & 0.80 & 0.33 \\
\hline
\end{tabular}

Note: Values in the same row without a shoulder note or noted with common letters were not significant $(\mathrm{P}>0.05)$, and those without a shared letter are significantly different $(\mathrm{P}<0.05)$. CG, $\mathrm{AL}, \mathrm{AM}, \mathrm{AH}$ are the groups where wheat straw replaced alfalfa, respectively, $0 \%, 20 \%, 40 \%, 60 \%$.

\subsection{Effect of Wheat Straw Replacing Alfalfa on Serum Biochemical Indexes}

As shown in Table 7, there was no significant difference in serum $\beta$-hydroxybutyrate, triglyceride, and urea nitrogen groups $(\mathrm{P}>0.05)$, while serum glucose and volatile fatty acids were significantly affected by the diet $(\mathrm{P}<0.01)$. The concentration of serum glucose in the $\mathrm{AH}$ group was significantly higher than that of CG group $(\mathrm{P}<0.05)$. The concentration of serum free fatty acid (FFA) in the CG group was significantly higher than those in other three groups $(\mathrm{P}<$ $0.05)$, and the proportion of wheat straw replacement increases were accompanied by significantly decreased serum FFA $(\mathrm{P}<0.05)$.

\subsection{Effect of Wheat Straw Replacing Alfalfa on Production Efficiency}

Table 8 shows the effect of wheat straw replacing some of the imported alfalfa hay in the diet on the economic benefits. Calculated according to the ratio of raw materials and prices, feed intake, milk yield and milk price, it was found that after using wheat straw to replace the imported alfalfa hay in the diet, the cost per $\mathrm{kg}$ of feed showed a clear downward trend, from 1.16 yuan $/ \mathrm{kg}$ to 1.13 yuan $/ \mathrm{kg}$, 1.10 yuan $/ \mathrm{kg}$ and 1.06 yuan $/ \mathrm{kg}$, without considering other costs (such as labor, machinery, etc.) other than feed in the economic benefit calculation process, assuming that the other costs are the same in all the groups. Compared with the control group, the benefit increased by 3.35 yuan per day in the $20 \%$ replacement group, increased by 0.03 yuan per day in the $40 \%$ replacement group, decreased by 7.56 yuan per day in the $60 \%$ replacement group.

\section{Discussion}

\subsection{Nutrient Intake and Apparent Digestibility}

Carbohydrates in feeds are generally classified into neutral detergent fibers (NDF) and non-fibrous carbohydrates (NFC) depending on their main site of presence [10]. NDF is predominantly present in the cell wall, while NFC is 
Table 7. Effect of wheat straw replacing alfalfa on serum biochemical indexes of dairy cows.

\begin{tabular}{ccccccc}
\hline Item & CG & AL & AM & AH & SEM & P-value \\
\hline TG (mmol/L) & 0.79 & 0.79 & 0.80 & 0.88 & 0.20 & 0.31 \\
BUN (mmol/L) & 3.46 & 3.13 & 3.76 & 3.44 & 0.10 & 0.20 \\
Glucose (mmol/L) & $8.53^{\mathrm{b}}$ & $9.77^{\mathrm{ab}}$ & $10.22^{\mathrm{a}}$ & $11.33^{\mathrm{a}}$ & 3.79 & $<0.01$ \\
FFA (umol/L) & $373.55^{\mathrm{c}}$ & $321.03^{\mathrm{a}}$ & $286.85^{\mathrm{b}}$ & $277.01^{\mathrm{a}}$ & 6.87 & $<0.01$ \\
BHBA (umol/L) & 0.87 & 0.83 & 0.86 & 0.84 & 0.01 & 0.70 \\
\hline
\end{tabular}

Note: Values in the same row without a shoulder note or noted with common letters were not significant $(\mathrm{P}>0.05)$, and those without a shared letter are significantly different $(\mathrm{P}<0.05) . \mathrm{CG}, \mathrm{AL}, \mathrm{AM}, \mathrm{AH}$ are the groups where wheat straw replaced alfalfa, respectively, $0 \%, 20 \%, 40 \%, 60 \%$.

Table 8. Effect of wheat straw replacing alfalfa on production benefit.

\begin{tabular}{cccccccc}
\hline Item & $\begin{array}{c}\text { Average milk } \\
\text { production } \\
(\mathrm{kg})\end{array}$ & $\begin{array}{c}\text { Effectiveness } \\
\text { (yuan) }\end{array}$ & $\begin{array}{c}\text { Actual feed } \\
\text { intake }(\mathrm{kg})\end{array}$ & $\begin{array}{c}\text { Feed price } \\
\text { (yuan) }\end{array}$ & $\begin{array}{c}\text { Daily feed } \\
\text { cost (yuan) }\end{array}$ & $\begin{array}{c}\text { Produce } \\
\text { benefit } \\
\text { (yuan) }\end{array}$ & $\begin{array}{c}\text { Extra } \\
\text { income } \\
\text { (yuan) }\end{array}$ \\
\hline CG & 28.13 & 112.52 & 42.98 & 1.16 & 49.86 & 62.66 & \\
$\mathrm{AL}$ & 29.33 & 117.32 & 45.40 & 1.13 & 51.30 & 66.02 & 3.35 \\
$\mathrm{AM}$ & 27.56 & 110.24 & 43.22 & 1.10 & 47.54 & 62.70 & 0.03 \\
$\mathrm{AH}$ & 26.07 & 104.28 & 45.96 & 1.07 & 49.18 & 55.10 & -7.56 \\
\hline
\end{tabular}

Note: The milk price was calculated at 4 yuan $/ \mathrm{kg}$. The additional benefit was the difference between the benefit of the test group and the control group. Diet cost: corn silage 360 yuan/ton, alfalfa 2400 yuan/ton, wheat straw 600 yuan/ton, distiller's grains 630 yuan/ton, beetroot 1850 yuan/ton, flaked corn 2100 yuan/ton, wheat bran 1600 yuan/ton, soybean meal 3100 yuan/ton, cottonseed 1800 yuan/ton, other 2750 yuan/ton. Kilogram milk feed cost $=$ diet cost $/$ milk production; total output $=$ milk yield $\times$ milk price; benefit (excluding other costs except for feed costs, assuming other costs are consistent across groups) $=$ gross output value-diet cost. $\mathrm{CG}, \mathrm{AL}, \mathrm{AM}$, and $\mathrm{AH}$ are the groups where wheat straw replaced alfalfa, respectively, at $0 \%, 20 \%, 40 \%$, and $60 \%$.

predominantly present in cellular contents. For lactating cows, roughage accounts for half or more of the diet and profoundly affects the energy and carbohydrate intake [11]. Obtaining the largest digestible carbohydrates from forage is the most important management goal, and the energy requirements for maintaining and lactating often exceed the energy consumed by the production cattle [12]. Forage NDF is the main factor affecting feed intake, and it also affects the rumen filling of high-yield dairy cows. Waldo (1986) suggested that dietary NDF content is the single chemical factor predicting DMI in dairy cows [13]. When fed corn silage with greater NDF digestibility, lactating cows consume more DM and produce more milk (Qiu et al. 2003) [14]. When replaced alfalfa hay with corn stover in cow's ration, it was found that as the grain size of the ration decreased, the digestibility of the fiber decreased, but DMI increased [15]. In our trial, the wheat straw was powdered, and the DMI increased with the increase in the level of the replacement. However, the observed DMI did not increase with the increasing proportion of substitution. DMI did not have a linear relationship 
with the proportion of substitution. Studies have shown that feed intake will increase when ruminants eat forages with lower dietary fiber contents. The results observed in this experiment are not consistent with these previous reports. The likely reason is that the cows were fed with different diets. Cows fed corn stover were significantly lower in $\mathrm{OM}, \mathrm{CP}, \mathrm{NDF}, \mathrm{ADF}$, and nitrogen utilization than those fed alfalfa and corn silage (Zhou Xiaoqiao 2015) [16]. The apparent CP digestibility in the corn stover group was significantly higher than that in the mixed roughage group (Xu Xiaoyan 2012) [17]. Compared with corn stover, alfalfa and corn silage had a significantly higher rumen degradation rate in DM, CP, NDF and ADF (Wang Dandan 2013) [18]. Experimental studies have shown that the digestibility of nutrients in alfalfa hay is higher (Zhang Tao 2003) [19]. According to published reports, the proportion and combination of roughage have different effects on the apparent digestibility of nutrients in cows. There were significant differences in OM digestibility and CP digestibility between the control group and the test groups [20]. Hao Yingfei (2007) used alfalfa and corn stover in different proportions and found that the apparent digestibility of DM did not decrease along with the increase of corn stover proportion. When the alfalfa to corn stover ratio was $25 \%$, the apparent digestibility of DM decreased [20]. Hou Yujie (2014) used four types of roughages, alfalfa, oat grass, leymus and rice straw to prepare isocaloric isonitrogenous rations, with the same NDF, FNDF and NFC. He found that different roughage sources had no effect on the apparent digestibility of DM and OM [21]. Wang Zhijun (2015) found that the highest value of forage grasses had the highest OM and DM digestibility [22]. In 2009, Zhu Qing fed cows with Leymus chinensis and conventional corn stover, and found that the milk yield of Leymus chinensis group was higher than that of the alfalfa group [23].

Hou Yujie (2014) used four types of roughages in rations and found that the apparent OM digestibility was not different among groups, but NDF and ADF digestibility was significantly different between the alfalfa groups and the rice straw group [21]. In this experiment, the increased in the proportion of wheat straw replacement did not significantly affect the apparent ADF digestibility. The test groups (AL, AM, AH group) were numerically higher in apparent ADF digestibility than the control group (CG group). In addition, the reason for this phenomenon is due to the combined effect between alfalfa hay and wheat straw [24]. The mechanism may be: alfalfa itself contains more rumen metabolizable protein which provides a sufficient source of nitrogen for rumen microorganisms. Wheat straw itself contains a higher fiber content [25]. Rumen microorganisms have a powerful fermentation function that can make full use of this nutrient source [26]. Therefore, wheat straw provided a large amount of carbon source for rumen microorganisms.

\subsection{Nitrogen Utilization and Nitrogen Metabolism}

Dietary nitrogen intake is a major factor in determining the milk nitrogen effi- 
ciency in cows (Huhtanen et al. 2008) [27]. Nitrogen metabolism is closely related to the content and type of volatile fatty acids in the rumen [28]. Ammonia nitrogen concentrations in the rumen are often used as a reference standard. In this experiment, there were no significant differences in milk protein yield among CG, AL and AM. The utilization of nitrogen by ruminants is related to the rumen degradation rate of dietary nitrogen and the availability of energy from microbes.

Studies have found that nitrogen utilization is promoted when the rumen degradation rate of nitrogen is synchronized with the available energy provided by the microorganisms. The protein levels were the same among the 4 groups, but the levels of nitrogen intake were different. This is mainly because the dry matter intake is different among the four groups, and the apparent digestibility of the crude protein in the diet is also different. Therefore, there were differences in the levels of nitrogen intake among groups. The nitrogen intake of the CG and AL groups was similar in value and significantly greater than that in the AM and $\mathrm{AH}$ groups. Reports indicate that increasing the proportion of NSC in grasses-based diets and lowering the proportion of structural carbohydrates improve nitrogen utilization in lactating dairy cows and increase microbial protein synthesis (Reis and Combs 2000) [29]. When high-yield dairy cows are fed a large amount of high-quality protein, microbial protein degradation products are not directly involved in microbial protein synthesis (MPS), which often produces rumen $\mathrm{NH}_{3}$, which is eventually excreted in the form of urine $\mathrm{N}$ [30]. Excess ammonia in the rumen is absorbed into the blood through the rumen wall, and part of it is swallowed back into the rumen through saliva in the form of urea, and the other part enters the liver and is excreted in the form of urea (Kennedy 1980) [31]. Although the levels of NDF and NFC were different in the four groups of diets, there was no significant difference in urinary nitrogen excretion. The addition of wheat straw to the diet did not significantly affect the excretion of urinary nitrogen. Regarding the nitrogen balance, the CG group is similar in value compared with the AM and $\mathrm{AH}$ groups, while the AL group is numerically the highest. The possible reason is that a combined effect has occurred. The rumen environment is an important factor affecting nitrogen metabolism, but now the dairy industry is seeking the greatest production benefit [32]. Cows are fed with a large amount of fermentable organic matter, causing rapid fermentation of organic matter (NFC) in the rumen, making cows prone to subacute rumen acidosis.

\subsection{Rumen Fermentation}

When high yield cows are fed a ration containing more than $45 \%$ of high-concentrate (based on DM), the rumen $\mathrm{pH}$ generally falls to 5.3 or 5.0 during fermentation stage from the usual average $\mathrm{pH} 6.0$ or 6.1 before feeding in the morning [33]. In fact, the rumen $\mathrm{pH}$ may be lower than these average levels for a fairly long time during the feeding period. Because the magnitude of rumen $\mathrm{pH}$ 
fluctuation is not fully characterized, the $\mathrm{pH}$ measurement may be misleading. Grovum (1973) found that NSC degraded faster than NDF. The rapid degradation of NSC may lead to the accumulation of VFA, which lowers the rumen $\mathrm{pH}$ and increases the osmotic pressure. NDF is difficult to digest, which produced a small amount of acids. Therefore, the concentration of dietary NDF is negatively correlated with the rumen pH (NRC 2001) [34] [35]. In this study, except that the $\mathrm{AM}$ group had a lower rumen $\mathrm{pH}$ than the $\mathrm{CG}$ group, the groups $\mathrm{AL}$ and $\mathrm{AH}$ had higher rumen $\mathrm{pH}$ values than the CG group, indicating that the replacement of alfalfa with wheat straw could alleviate the rumen fermentation to some extent [36].

Diet is an important factor affecting rumen stability, and rumen $\mathrm{pH}$ is an indirect indicator of rumen stability. In this experiment, the use of wheat straw gradient substituting alfalfa had no significant effect on the rumen $\mathrm{pH}$ of dairy cows. The $\mathrm{pH}$ values were all within the normal range $(5.5-6.8)$. This indicates that the rumen environment is relatively stable. The test diets did not cause significant changes in rumen fermentation function. Beauchemin et al. (1995) and Agbagladohnani et al. (2001) reported that the addition of corn fiber to diets did not affect rumen $\mathrm{pH}$ or increase $\mathrm{pH}$. They explained that it may be because the carbohydrate portion of the corn fiber feed WCGF is mainly composed of fermentable fiber rather than non-structural carbohydrates [37] [38].

\subsection{Lactation}

Dairy cow milk production is particularly susceptible to fluctuation and unstable. Zhou Juan (2007) believes that roughage is the most critical factor among many factors affecting milk production [39]. Of course, animals can feed on energy, and only when they meet the needs can they have the "remaining power" to contribute. The composition of the roughage, the fiber type of the forage, the ratio of roughage to concentrates, etc. all affect the rumen metabolism, which in turn affects milk yield and milk composition [40] [41] [42]. The appropriate treatment of the straw to ensure that the feed intake of the cow can meet the lactation performance needs (Zhang Qian 2010) [43]. Cows fed mixed alfalfa and corn silage, compared with those fed corn stover with the same dry matter content as the single roughage source, had increased DMI, significantly increased milk yield and milk protein rate, because the mixed roughage sources have higher CP levels (Zhou Xiaoqiao 2015) [16].

In this experiment, wheat straw was used to supplement the crude fiber through the alfalfa + wheat straw + concentrate mode, which alleviated the rumen fermentation speed and improved the status of the cow. DMI plays an important role in dairy production. It determines the amount of nutrients that cows use to maintain and produce. When NDF in the diet is derived solely from roughage, DMI is related to the NDF concentration of the TMR diet (Mertens 2009) [44]. Hou Yujie (2014) fed cows with four different roughage sources, and found that DMI of the cows was close and the milk yield was similar. This test 
also reached the same conclusion [21]. The DMI was similar between the groups, and the milk yield was similar. In this experiment, the CG group had the highest DMI. Its apparent CP digestibility was also numerically highest. This means that it has a high intake of nitrogen. Our experimental data also confirms this. From this point of view, the intake of food, protein content affects the content of milk protein, in fact, is ultimately the level of true nitrogen intake. Once mastered this law, we can design a diet that is more conducive to the intake of dairy cows, solve the palatability of poor-quality roughage, and provide a theoretical basis for the development of new forage resources [45].

Gencoglu et al. fed diets of wheat stalks and chopped sorghum, respectively, found that the yield of $4 \%$ standard milk and energy-corrected milk was similar (Gencoglu et al. 2008) [46]. The 4\% standard milk and energy-corrected milk in this test are not affected by the diet, which is consistent with the results of the study. Of course, there are also different reports. Wang Jinhe et al. (2010) reported that the amount of milk produced in the hay group was significantly higher than that in the corn stalk group [47]. And Zhu Wen (2013) reported that the milk yield of dairy cows fed with cockroaches was higher than that of cows fed corn stalks [48]. When converted to $4 \%$ fat-corrected milk, feeding cockroaches was higher than that of corn stalks. The possible reason is that this test is designed to be equivalent to the same nitrogen level. In addition, $4 \%$ milk yield and milk protein production in dairy cows may be related to dietary intestinal absorption protein and small intestinal absorbable microbial protein (Huhtanen et al. 2008) [27].

In 2017, Wang proposed the concept that metabolizable proteins have a regulating effect on milk production. Metabolizable proteins are precursors of milk protein synthesis (NRC 2001). That is to say, the precursor substance of milk protein synthesis is metabolizable protein. Therefore, we can have such an inference: the more precursors are provided to cattle in the feed, the simpler the acquisition process is, the more the precursor supplies for milk protein synthesis, theoretically the more milk protein production there can be [49]. It also provides a theoretical basis for the interpretation of milk protein reduction caused by feeding inferior roughage. In this test, the amount of lactose, milk protein, and milk fat was not significantly affected by the diets. Although the nutrient content of wheat straw is lower than that of alfalfa, it can be adjusted to be isonitrogenous and isocaloric. Therefore, we can think that the metabolizable protein that such diet can provide should be similar.

\subsection{Blood Biochemical Indexes}

The growth hormone $(\mathrm{GH})$ level was the highest in the CG group ( $0 \%$ replacement group) and the lowest in the AM group. It is consistent with the lowest concentration of glucose in the serum of the CG group. The possible reason is that growth hormone inhibits blood glucose level. The results of this study are the same as reported by Lucy M C (2014). When the blood glucose concentra- 
tion increases, it will stimulate the islet B cells to secrete more insulin, and under the action of insulin, the blood glucose concentration will return to a normal value [50]. When blood glucose level drops, it stimulates islet A cells to secrete more glucagon, and blood glucose levels rise to normal. The insulin content of the CG group was the highest, probably due to a higher the metabolic level of the CG group. Insulin-like growth factor is also a hormone that regulates blood sugar. It regulates the liver uptake of glucose to synthesize glycogen. Thus, it has the effect of lowering blood sugar. The CG group has the highest blood glucose in value, the AL group was the lowest in value, and the difference between the two groups was significant.

As early as 1973, Blowey et al. believed that the three components of glucose, urea and albumin in the blood were the indicators for the protein and energy status of dairy cows [51]. The change in its content can reflect the body's absorption, transport and metabolic homeostasis of sugar. A decrease in albumin concentration reflects insufficient protein intake. Serum urea nitrogen is an important indicator of the protein metabolism of the animal. A decrease in the concentration of urea nitrogen indicates insufficient protein intake or excessive energy intake. After feeding different ratios of concentrates and roughage, than wheat-type diets, the increase in the ratio of the concentrate to the roughage was accompanied by a significant increase in serum glucose content. However, there was no significant change in serum total protein, albumin, and urea nitrogen content (Zhang Litao 2013) [52]. Glucose concentration is not sensitive to changes in energy. Therefore, the use of glucose concentration as an indicator of monitoring energy has certain limitations. When feeding alfalfa, oats, leymus and straw, the blood glucose concentration has a narrow range, and the difference was not significant. The difference in blood glucose concentration between the CG group and the AL group was not significant, but it was significantly different from the AM and $\mathrm{AH}$ groups. It is indicated that the difference in blood glucose concentration is not significant when replacing $20 \%$ of alfalfa. In addition, the blood glucose concentration and the concentration of glucagon are inconsistent. This may be the blood glucose concentration is regulated two-ways, and is the result of a combination of multiple mechanisms. Blood sugar changes cannot be judged by a single hormone.

The serum urea nitrogen content reflects the metabolism of the protein and can reflect the balance of the rumen degradable protein and carbohydrate in the diet [53]. The urea nitrogen in the blood is derived from degraded dietary proteins and ammonia that is absorbed into the blood from the rumen [54]. Its concentration in the blood reflects the efficiency of nitrogen use in the diet (Kanjanapruthipong et al. 2006) [55]. The difference in urea nitrogen between the groups in this test was not significant. The content of urea nitrogen in the AL group was the smallest, which was inconsistent with the research results of Zhang Xiaoli (2006) [56]. The possible reason is that although alfalfa is a high-quality forage, contains a large amount of high-quality fermentable carbo- 
hydrates, and contains a reasonable pattern of amino acids, when wheat straw is used instead of alfalfa, a combined effect may occur.

\subsection{Effect on Economic Benefit}

As can be seen from Table 8, as the proportion of wheat straw replacing alfalfa increases, the price per unit of feed decreases. Compared with the control group, the additional production benefits of the AL, AM, and AH groups were, respectively, an increase by 3.35 yuan, an increase of 0.03 yuan, and a decrease of 7.56 yuan. The factor that affects the benefit is milk production. As can be seen from Table 4, the effect of diet on the average milk yield of each group was not significant. The average milk yields of the CG group, the AL group, the AM group, and the AH group were $28.13 \mathrm{~kg}, 29.33 \mathrm{~kg}, 27.56 \mathrm{~kg}$, and $26.07 \mathrm{~kg}$, respectively. There was no statistically significant difference among the groups. However, the average milk yield of the AM group and the AH group were numerically smaller than the control group, while the average milk yield of the AL group was numerically larger than the control group. In this regard, we believe that the combined effect of dietary formulas may have a greater impact on the lactation performance of dairy cows $4 \%$ fat correct milk, energy-corrected milk, and lactation net energy were not significantly different between groups. However, the yield of the AL group is the largest in numerical value. The feeding efficiency was only significantly different between the AL group and the AH group, and the feeding efficiency of the AL group was also numerically the largest. Taken together, a $20 \%$ substitution can produce greater economic benefits.

\section{Conclusions}

Under an isocaloric and isonitrogenous condition, the use of wheat straw powder to replace part of the alfalfa in the diet had no significant effect on rumen fermentation in dairy cows. Each group can have normal fermentation. As the wheat straw powder increases, the feed intake of dairy cows also increases. However, there was no significant effect on the apparent digestibility of neutral detergent fibers and acid detergent fibers.

The milk protein percentage and milk fat percentage of the added straw powder group were larger than those of the unsubstituted group. If only milk production is concerned, replacement of $20 \%$ alfalfa with wheat straw powder can improve the production performance of dairy cows, resulting in greater economic benefits.

\section{Acknowledgements}

I carried out this study in October 2017 in Jin Lan dairy farm, Taian. The study was financially supported by the earmarked fund for Modern Agro-industry Technology Research System of China (CARS-36), Cattle Agro-industry Technology Research System of Shandong Province (SDAIT-09-06), Natural Science Fund of China (31572427) (31372340), Key Research and Development Project 
of Shandong Province (2016GNC110013), National Key Research and Development Program of China (2017YFD0500502) and Taishan Scholar Project.

\section{Conflicts of Interest}

The authors declare no conflicts of interest regarding the publication of this paper.

\section{References}

[1] Shaver, R.D., Satter, L.D. and Jorgensen, N.A. (1988) Impact of Forage Fiber Content on Digestion and Digesta Passage in Lactating Dairy Cows. Journal of Dairy Science, 71, 1556-1565. https://doi.org/10.3168/jds.S0022-0302(88)79719-2

[2] Waldo, D.R. and Jorgensen, N.A. (1981) Forages for High Animal Production: Nutritional Factors and Effects of Conservation. Journal of Dairy Science, 6, 1207-1229. https://doi.org/10.3168/jds.S0022-0302(81)82697-5

[3] Murphy, M., Åkerlind, M. and Holtenius, K. (2000) Rumen Fermentation in Lactating Cows Selected for Milk Fat Content Fed Two Forage to Concentrate Ratios with Hay or Silage. Journal of Dairy Science, 83, 756-764.

https://doi.org/10.3168/jds.S0022-0302(00)74938-1

[4] Robinson, P.H. and Mcqueen, R.E. (1997) Influence of Level of Concentrate Allocation and Fermentability of Forage Fiber on Chewing Behavior and Production of Dairy Cows. Journal of Dairy Science, 80, 681-691. https://doi.org/10.3168/jds.S0022-0302(97)75987-3

[5] Sudweeks, E.M. (1977) Chewing Time, Rumen Fermentation and Their Relationship in Steers as Affected by Diet Composition. Journal of Animalence, 44, 694-701. https://doi.org/10.2527/jas1977.444694x

[6] Kalscheur, K.F., Vir, L.B., Glenn, B.P. and Kohn, R.A. (2006) Milk Production of Dairy Cows Fed Differing Concentrations of Rumen-Degraded Protein. Journal of Dairy Science, 89, 249-259. https://doi.org/10.3168/jds.S0022-0302(06)72089-6

[7] Oba, M. and Allen, M.S. (1999) Evaluation of Importance of Digestibility of Neutral Detergent Fiber from Forage: Effects on Dry Matter Intake and Milk Yield of Dairy Cows. Journal of Animal Science, 82, 589-596. https://doi.org/10.3168/jds.S0022-0302(99)75271-9

[8] Beauchemin, K.A. and Buchanan-Smith, J.G. (1989) Effects of Dietary Neutral Detergent Fiber Concentration and Supplementary Long Hay on Chewing Activities and Milk Production of Dairy Cows. Journal of Dairy Science, 72, 2288-2300. https://doi.org/10.3168/jds.S0022-0302(89)79360-7

[9] Leonardi, C. and Armentano, L.E. (2003) Effect of Quantity, Quality, and Length of Alfalfa Hay on Selective Consumption by Dairy Cows. Journal of Dairy Science, 86, 557-564. https://doi.org/10.3168/jds.S0022-0302(03)73634-0

[10] Feng, Y. (2004) Ruminant Nutrition. Science Press.

[11] Gill, M., Rook, A.J. and Thiago, L.R.S. (1988) Factors Affecting the Voluntary Intake of Roughages by the Dairy Cow. In: Garnsworthy, P.C., Ed., Nutrition and Lactation in the Dairy Cow, Butterworths, London, 262-279.

https://doi.org/10.1016/B978-0-408-00717-7.50020-4

[12] Baile, C.A. and Forbes, J.M. (1974) Control of Feed Intake and Regulation of Energy Balance in Ruminants. Physiological Reviews, 54, 160-214.

https://doi.org/10.1152/physrev.1974.54.1.160 
[13] Glenn, B.P. and Waldo, D.R. (1986) Alfalfa and Orchardgrass Silages Treated with Formaldehyde and Formic Acid or Anhydrous Ammonia for Heifers. Journal of Dairy Science, 69, 1317-1328. https://doi.org/10.3168/jds.S0022-0302(86)80538-0

[14] Qiu, X., Eastridge, M.L. and Wang, Z. (2003) Effects of Corn Silage Hybrid and Dietary Concentration of Forage NDF on Digestibility and Performance by Dairy Cows. Journal of Dairy Science, 86, 3667-3674. https://doi.org/10.3168/jds.S0022-0302(03)73972-1

[15] Liu, Y. (2013) Effect of Alfalfa Hay Substituting Part of Concentrate on the Production of Dairy Cows and Economic Profit. Henan Agricultural University, Zhengzhou.

[16] Zhou, X.Q. (2015) Effect of Dietary Forage Sources and Energy Supply on Milk Protein Syntheses and Regulation in Lactating Dairy Cows. Northeast Agricultural University, Haerbin.

[17] Xu, X. (2012) Nutritional and Feeding Value Comparison of Two Diets Based on Different Roughage for Dairy Cows. Yangzhou University, Yangzhou.

[18] Wang, D. (2013) Diversity of Ruminal Fiber Degrading Bacteria and Protein-Degrading Bacteria. Gansu Agricultural University, Lanzhou.

[19] Zhang, T. and Hu, Y. (2003) Application of Alfalfa Products in Dairy Cow Diets. Chinese Herbivore Science, 23, 39-41.

[20] Hao, Y. (2007) The Effect of Different Ratio Forages on Digestion Metabolism and Performance of Dairy Cattele. Northeast Agricultural University, Haerbin.

[21] Hou, Y. (2014) Rumen Degradation Characteristics of Forages and NDF Sources on Dairy Cows Performance and Blood Biochemical Parameter. Yangzhou University, Yangzhou.

[22] Wang, Z., Ge, G., Gao, J. and Wang, X. (2015) Research of Associative Effects of Alfalfa, Astragalus adsurgens, Gaodan Grass, Chinese Pennisetum and Ryegrass. Journal of Animal Nutrition, 27, 3628-3635.

[23] Zhu, Q., Zhao, H., Xie, X. and Xu, Q. (2009) Influence of Different Forage on Dairy Cattle Milk Yield and Milk Composition. Feed Industry, 30, 25-27.

[24] Hao, X. (2017) Study on the Feeding Effects of Replacing Alfalfa Hay with the Combination of Dry Corn Gluten Feed and Chinese Leymusin Dairy Cows' Ration. Northeast Agricultural University, Haerbin.

[25] He, M. (2005) The Effects of Roughage Particle Size in TMR on Chewing Activity and Rumen Fermentation of Dry Cows. China Agricultural University, Beijing.

[26] Allen, M.S. (1996) Physical Constraints on Voluntary Intake of Forages by Ruminants. Journal of Animal Science, 74, 3063. https://doi.org/10.2527/1996.74123063x

[27] Huhtanen, P., Rinne, M. and Nousiainen, J. (2008) Effects of Silage Soluble Nitrogen Components on Metabolizable Protein Concentration: A Meta-Analysis of Dairy Cow Production Experiments. Journal of Dairy Science, 91, 1150-1158. https://doi.org/10.3168/jds.2007-0323

[28] Huhtanen, P., Seppälä, A. and Ahvenjärvi, S. (2008) Prediction of in Vivo Neutral Detergent Fiber Digestibility and Digestion Rate of Potentially Digestible Neutral Detergent Fiber: Comparison of Models. Journal of Animal Science, 86, 2657-2669. https://doi.org/10.2527/jas.2008-0894

[29] Reis, R.B. and Combs, D.K. (2000) Effects of Increasing Levels of Grain Supplementation on Rumen Environment and Lactation Performance of Dairy Cows Grazing Grass-Legume Pasture. Journal of Dairy Science, 83, 2888-2898. https://doi.org/10.3168/jds.S0022-0302(00)75189-7 
[30] Van Vuuren, A.M., Valk, H. and De, V.H. (1993) Effects of Partial Replacement of Ryegrass by Low Protein Feeds on Rumen Fermentation and Nitrogen Loss by Dairy Cows. Journal of Dairy Science, 76, 2982-2993. https://doi.org/10.3168/jds.S0022-0302(93)77637-7

[31] Kennedy, P.M. (1980) The Effects of Dietary Sucrose and the Concentrations of Plasma Urea and Rumen Amonia on the Degradation of Urea in the Gastrointestinal Tract of Cattle. British Journal of Nutrition, 43, 125-140. https://doi.org/10.1079/BJN19800072

[32] Wang, G. (2000) Cattle Raisin. China Agricultural Press, Beijing.

[33] Valdez, F.R., Bush, L.J., Goetsch, A.L. and Owens, F.N. (1986) Effect of Steroidal Sapogenins on Ruminal Fermentation and on Production of Lactating Dairy Cows. Journal of Dairy Science, 69, 1568-1575. https://doi.org/10.3168/jds.S0022-0302(86)80573-2

[34] Weiss, W.P., Garnsworthy, P.C. and Wiseman, J. (2002) Dairy Feeding Standards in the USA. NRC 2001.

[35] Grovum, W.L. and Williams, V.J. (1973) Rate of Passage of Digesta in Sheep 4 Passage of Marker through the Alimentary Tract and the Biological Relevance of Rate Constants Derived from the Changes in Concentration of Marker in Faeces. British Journal of Nutrition, 30, 313-329. https://doi.org/10.1079/BJN19730036

[36] Zorrillarios, J., Owens, F.N., Horn, G.W. and Mcnew, R.W. (1985) Effect of Ammoniation of Wheat Straw on Performance and Digestion Kinetics in Cattle. PLoS ONE, 8, 16. https://doi.org/10.1371/journal.pone.0083922

[37] Agbagladohnani, A., Noziere, P., Clement, G. and Doreau, M. (2001) In Sacco Degradability, Chemical and Morphological Composition of 15 Varieties of European Rice Straw. Animal Feed Science \& Technology, 94, 15-27. https://doi.org/10.1016/S0377-8401(01)00296-6

[38] Beauchemin, K.A. (1991) Effects of Dietary Neutral Detergent Fiber Concentration and Alfalfa Hay Quality on Chewing, Rumen Function, and Milk Production of Dairy Cows. Journal of Dairy Science, 74, 3140-3151. https://doi.org/10.3168/jds.S0022-0302(91)78499-3

[39] Zhou, J., Pan, Z. and Yang, H. (2007) Research and Application of Feed Cellulase. Livestock and Feed Science, 28, 50-53.

[40] Li, H., Kong, X. and Wu, G. (2007) Study on the Structural Layer of Crude Fiber in Roughage. Chinese Agricultural Science Bulletin, 23, 32-36.

[41] Mertens, D.R. (1997) Creating a System for Meeting the Fiber Requirements of Dairy Cows. Journal of Dairy Science, 80, 1463-1481. https://doi.org/10.3168/jds.S0022-0302(97)76075-2

[42] Zhu, W. (2013) Effects of Forage Sources on Milk Protein Precursors and Lactation Performance in Dairy Cows and Approach to the Mechanism. Zhejiang University, Hanghzou.

[43] Zhang, Q., Xia, J., Li, S. and Cao, Z. (2010) Effects of Different Dietary Proportion of Compacted Corn Straw and Chinese Wildrye on Rumen Fermentation and Performance in Dairy Cows. Journal of Animal Nutrition, 22, 474-480.

[44] Mertens, D.R. (1987) Predicting Intake and Digestibility Using Mathematical Models of Ruminal Function. Journal of Animal Science, 64, 1548-1558. https://doi.org/10.2527/jas1987.6451548x

[45] Lammers, B.P., Buckmaster, D.R. and Heinrichs, A.J. (1996) A Simple Method for the Analysis of Particle Sizes of Forage and Total Mixed Rations. Journal of Dairy 
Science, 79, 922-928. https://doi.org/10.3168/jds.S0022-0302(96)76442-1

[46] Gencoglu, H., Shaver, R. and Lauer, J. (2008) Brown Midrib Corn Sliage for Lactating Dairy Cows: A Contemporary Review.

[47] Wang, J., Li, A. and Zhao, Y. (2010) Effect of Different Roughage on Performance of Dairy Cows. Contemporary Livestock, 8, 32-33.

[48] Zhu, W., Fu, Y., Wang, B. and Wang, C. (2013) Effects of Dietary Forage Sources on Rumen Microbial Protein Synthesis and Milk Performance in Early Lactating Dairy Cows. Journal of Dairy Science, 96, 1727-1734. https://doi.org/10.3168/jds.2012-5756

[49] Wang, H. (2017) Effect of Exogenous Enzyme Preparation in Corn Straw-Based Diet on Growth Performance of Lambs and Mechanism of Its Action on Degradation of Fiber Structure. Chinese Academy of Agricultural Sciences, Beijing.

[50] Lucy, M.C., Butler, S.T. and Garverick, H.A. (2014) Endocrine and Metabolic Mechanisms Linking Postpartum Glucose with Early Embryonic and Foetal Development in Dairy Cows. Animal, 8, 82-90. https://doi.org/10.1017/S1751731114000482

[51] Blowey, R.W. (1973) Metabolic Profiles Some Aspects of Their Interpretation and Use in the Field. Veterinary Annual, 21-30.

[52] Zhang, L., Li, Y., Wang, J., Cui, X. and Meng, X. (2013) Effects of Different Neutral Detergent Fiber Level Diets on Growth Performance and Apparent Digestibility of Nutrients. Journal of Animal Nutrition, 25, 433-440.

[53] Xue, H., Yan, G. and Meng, Q. (2007) In Vitro Fermentation Kinetic Analysis of the Carbohydrate Fractions in Various Sections of Corn Stalks. Journal of Animal Husbandry and Veterinary, 38, 926-933. https://doi.org/10.1097/MOP.0b013e3283423f35

[54] Mao, H. and Feng, Y. (1991) Studies on the Improvement of Nutritive Value of Straw with the Treatment of Urea and Caleium Hydroxide. Chinese Journal of Animal Science, 5, 3-6.

[55] Kanjanapruthipong, J. and Thaboot, B. (2006) Effects of Neutral Detergents Fiber from Rice Straw on Blood Metabolites and Productivity of Dairy Cows in the Tropics. Asian Australasian Journal of Animal Sciences, 19, 356-362. https://doi.org/10.5713/ajas.2006.356

[56] Zhang, X. (2006) Effects of Alfalfa Hay Supplementation on Performance and Blood Parameters in Lactating Dairy Cows. Hebei Agricultural University, Baoding. 